
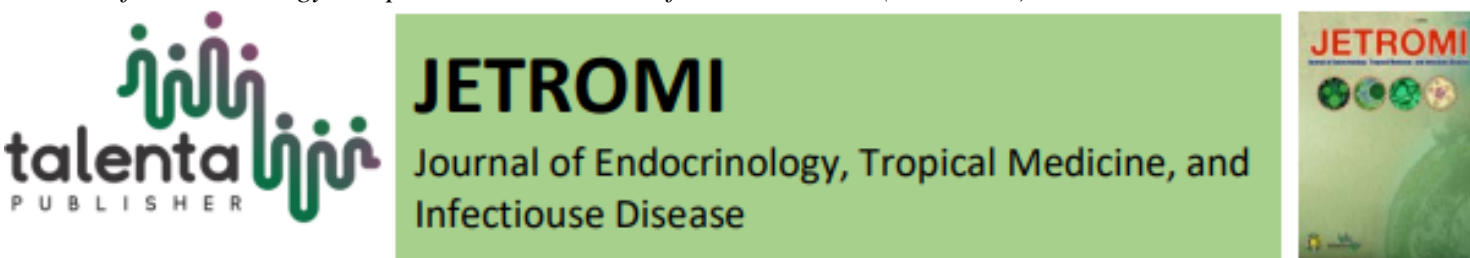

\title{
Differences In Inflammatory Parameters of Child-Pugh $B$ and Child-Pugh C Scores of Liver Cirrhosis With Hepatorenal Syndrome
}

\author{
Lider Olmen Panggabean ${ }^{1}$, Gontar Alamsyah Siregar ${ }^{2}$, Masrul Lubis ${ }^{2}$ \\ ${ }^{1}$ Department of Internal Medicine, Faculty of Medicine, University of Sumatera Utara, Medan, North \\ Sumatera, Indonesia \\ ${ }^{2}$ Division of Gastroenterology, Department of Internal Medicine, Faculty of Medicine, Universitas \\ Sumatera Utara
}

\begin{abstract}
Background: Child-Pugh score is used to predict the poor prognosis of liver cirrhosis patients. The study objectives analyzed differences in inflammatory parameters of Child-Pugh B and Child-Pugh C of liver cirrhosis with hepatorenal syndrome. Method: Desain's study is cross-sectional in liver cirrhosis patients with hepatorenal syndrome. This research was approved by the Health Research Ethics Commission FK USU / RSUP H. Adam Malik Medan and meets the criteria of inclusion or exclusion. Diagnosis of Liver cirrhosis Child-Pugh B and Child-Pugh C score is done by clinical examination, laboratory, and ultrasound, CT scan, MRI. The hepatorenal syndrome was diagnosed using Criteria International Ascites Club, 2007. Results: The sample number of this study was 26 liver cirrhosis with hepatorenal syndrome patients consisting of Child-Pugh B patients 9 patients and Child-Pugh C patients 17 patients. The comparison between Child-Pugh B and ChildPugh $\mathrm{C}$ has significant differences in leukocyte, $\mathrm{Na}, \mathrm{Cl}$, SGOT, and CTP. There is a significant correlation between CTP and leukocytes, platelets, Cl, creatinine, GFR, albumin, total bilirubin, and glued bilirubin. Conclusion: There is no clear difference in the inflammatory parameters of the Child-Pug B and Child-Pug C scores in liver cirrhosis with hepatorenal syndrome.
\end{abstract}

Keywords: Liver-Cirrhosis, Hepato-Renal-Syndrome, Child-Pugh Score, CTP

\begin{abstract}
Abstrak. Latar belakang: Skor Child-Pugh digunakan untuk memprediksi prognosis yang buruk pasien sirosis hati. Tujuan penelitian menganalisis perbedaan parameter peradangan dari skor Child-Pugh B dan Child-Pugh C sirosis hati dengan sindrom hepatorenal. Metode: Desain studi adalah potong lintang pada pasien sirosis hati dengan sindrom hepatorenal. Penelitian ini disetujui oleh Komisi Etik Penelitian Kesehatan FK USU/RSUP H. Adam Malik Medan dan memenuhi kriteria inklusi atau ekslusi. Diagnosis skor Liver cirrhosis Child-Pugh B dan Child-Pugh C dilakukan dengan pemeriksaan klinis, laboratorium dan USG, CT scan, MRI. Sindroma hepatorenal didiagnosis menggunakan Criteria International Ascites Club, 2007. Hasil: Jumlah sampel penelitian ini adalah 26 pasien sirosis hati dengan sindrom hepato renal yang terdiri dari pasien Child-Pugh B 9 pasien dan pasien Child-Pugh C 17 pasien. Perbandingan antara Child-Pugh B dan Child-Pugh C memiliki perbedaan signifikan pada leukosit, $\mathrm{Na}, \mathrm{Cl}, \mathrm{SGOT}$ dan CTP. Ada korelasi yang signifikan antara CTP dengan leukosit, trombosit, Cl, kreatinin, GFR, Albumin, bilirubin total dan bilirubin direk.
\end{abstract}

\footnotetext{
*Corresponding author at: Department of Internal Medicine, Faculty of Medicine, University of Sumatera Utara, Medan, North Sumatera, Indonesia

E-mail address: olmenp@gmail.com
} 
Kesimpulan: Tidak ada perbedaan yang jelas dalam parameter peradangan dari skor ChildPug B dan Child-Pug C pada sirosis hati dengan sindrom hepatorenal.

Kata kunci: Hati-Sirosis, Hepato-Renal-Syndrome, Skor Child-Pugh, CTP

Received 27 January 2021 | Revised 27 February 2021 | Accepted 28 February 2021

\section{Introduction}

Reviewing of literature, there are limited data regarding the use of the Child-Pugh score to predict medical utilization in patients with acute hepatitis. The Child-Pugh score was noted to predict poor prognosis in patients with cirrhosis.[1] or hepatocellular carcinoma [2]. Zhu et al [3] found that the Child-Pugh score was an independent determinant for the length of hospital stay (LOHS) after hepatectomy in patients with hepatocellular carcinoma. The Child-Pugh score had positive impacts on both the medical expense and the LOHS. Higher Child-Pugh scores were referred to hepatic decompensation that might be explained by the higher medical expense the was paid and LOHS was also longer in these patients [4] Liver cirrhosis is classified into two stages: compensated and decompensated liver cirrhosis. Decompensated cirrhosis is characterized by the presence of ascites, variceal bleeding, and hepatic encephalopathy, with a difference of 2 years of survival versus 12 years of the compensated disease. [5] The main cause of the transition from a compensated to a decompensated stage is portal hypertension. [6] The occurrence of further decompensation (i.e. refractory ascites, spontaneous bacterial peritonitis, hepatorenal syndrome (HRS), and recurrence of hepatic encephalopathy and variceal bleeding) shortens the survival. The hepatorenal syndrome is one characterized by a very poor prognosis, [7] therefore it is necessary to identify it early and understand the syndrome so other causes of renal failure can be excluded so a medical treatment or transplant can start as soon as possible.

Modified Child Turcotte-Pugh (CTP) score, by adding creatinine, performed similarly to model for end-stage liver disease score. Hepatic encephalopathy and hyponatremia (as an index of ascites), both components of CTP score, add to the prognostic performance of the model for endstage liver disease score. [8] Our study was a pilot study and was conducted to find out the correlation between medical utilization and the Child-Pugh score.

The study objectives compared inflammatory and electrolyte parameters between Child-Pugh B and Child-Pugh $\mathrm{C}$ in liver cirrhosis patients with hepatorenal syndrome.

\section{Method}

The study is a cross-sectional design of 26 liver cirrhosis with hepatorenal syndrome patients. The studies are approved by the Ethics Commission for Health Research FK USU / RSUP H. Adam Malik Medan and meet the criteria of inclusion or exclusion. Diagnosis of Liver cirrhosis is carried out by clinical, laboratory and examinations of ultrasound, CT scan, MRI, Hepatorenal 
Syndrome diagnosed using the Criteria International Ascites Club, 2007, [9] Neutrophil Gelatin is associated Lipocalin (NGAL) urine using Elisa (Human Lipocalin-2/NGAL Immunoassay, R\&D System Inc), kidney function using Cockcroft and Gaul Formula, CTP using the calculator.

\section{Data Analysis}

Data univariate analysis is presented descriptively, displaying average data and standard deviations. Test normality of data using the Shapiro Wilk test. The bivariate analysis uses a Tindependent test if data is distributed normally. If data is not distributed normally used the MannWhitney test. Test Pearson correlation when distributed data is normal, and use spearman correlation if data is not distributed normally. Analysis using computer programs SPSS 23 (Statistical Product and for Social Sciences) and confidence intervals of 95\%, where $\mathrm{p}<0.05$.

\section{Results}

The sample number of this study was 26 patients liver cirrhosis with hepato renal syndrome consisting of Child-Pugh B 9 patient and Child-Pugh C 17 patients (table 1).

Table 1 Baseline Data of Patients

\begin{tabular}{|c|c|}
\hline Parameter & $\mathrm{N}=26$, Mean $\pm \mathrm{SD}$ \\
\hline Age, yr & $57.50 \pm 8.91$ \\
\hline $\mathrm{BW}, \mathrm{Kg}$ & $59.03 \pm 5.98$ \\
\hline $\mathrm{Hb}, \mathrm{gr} / \mathrm{dL}$ & $9.04 \pm 1.20$ \\
\hline Leukosit, sell/mm³ & $8128.07 \pm 2935.01$ \\
\hline Trombosit, sell/mm $\mathrm{mm}^{3}$ & $139730.76 \pm 39704.46$ \\
\hline $\mathrm{Na}, \mathrm{mEq} / \mathrm{L}$ & $130.80 \pm 8.15$ \\
\hline $\mathrm{K}, \mathrm{mEq} / \mathrm{L}$ & $40.56 \pm 13.23$ \\
\hline $\mathrm{Cl}, \mathrm{mEq} / \mathrm{L}$ & $98.73 \pm 8.96$ \\
\hline Ureum, mg/dL & $84.28 \pm 34.01$ \\
\hline Creatinin, mg/dL & $2.45 \pm 0.61$ \\
\hline GFR, mL/min/1.73 $\mathrm{m}^{2}$ & $28.53 \pm 10.31$ \\
\hline NGAL, ng/ml. & $13078.34 \pm 4513.94$ \\
\hline Albumin, mg/dL & $24.92 \pm 9.09$ \\
\hline SGOT, $\mu / l$ & $110.96 \pm 86.12$ \\
\hline SGPT, $\mu / l$ & $66.84 \pm 49.79$ \\
\hline Bilirubin Total, mg/dL & $6.06 \pm 7.28$ \\
\hline Bilirubin Direk, mEq/L & $4.06 \pm 5.56$ \\
\hline INR & $1.54 \pm 0.44$ \\
\hline CTP & $10.11 \pm 1.36$ \\
\hline
\end{tabular}

In table 2, the comparison between Child-Pug B and Child-Pug $\mathrm{C}$ has significant differences in leucocyte, $\mathrm{Na}, \mathrm{Cl}, \mathrm{SGOT}$ and CTP. 
Table 2 The Comparison Parameters between Child-Pug B and Child-Pug C in Liver Cirrhosis with Hepatorenal Syndrome Patients.

\begin{tabular}{|c|c|c|c|}
\hline Parameter & $\begin{array}{c}\text { Child-Pug B } \\
\mathrm{n}=9, \text { mean } \pm \text { SD }\end{array}$ & $\begin{array}{c}\text { Child-Pug C } \\
n=17, \text { mean } \pm \text { SD }\end{array}$ & $\mathbf{p}$ \\
\hline Age, yr & $59.33 \pm 8.74$ & $56.52 \pm 9.11$ & 0.457 \\
\hline $\mathrm{BW}, \mathrm{Kg}$ & $56.66 \pm 3.84$ & $60.29 \pm 6.62$ & 0.145 \\
\hline $\mathrm{Hb}, \mathrm{gr} / \mathrm{dL}$ & $9.52 \pm 0.83$ & $8.79 \pm 1.31$ & 0.147 \\
\hline Leukosit, sell/mm³ & $5891.11 \pm 2268.11$ & $9312.35 \pm 2565.68$ & $0.003^{*}$ \\
\hline Trombosit, sell $/ \mathrm{mm}^{3}$ & $126555.55 \pm 29698.95$ & $146705.88 \pm 43276.38$ & 0.225 \\
\hline $\mathrm{Na}, \mathrm{mEq} / \mathrm{L}$ & $136.77 \pm 3.11$ & $127.64 \pm 8.27$ & $0.004^{*}$ \\
\hline $\mathrm{K}, \mathrm{mEq} / \mathrm{L}$ & $40.66 \pm 6.16$ & $40.51 \pm 15.95$ & 0.978 \\
\hline $\mathrm{Cl}, \mathrm{mEq} / \mathrm{L}$ & $103.55 \pm 2.78$ & $96.17 \pm 10.07$ & $0.043^{*}$ \\
\hline Ureum, mg/dL & $71.55 \pm 35.60$ & $91.02 \pm 32.16$ & 0.170 \\
\hline Creatinin, mg/dL & $2.41 \pm 0.67$ & $2.47 \pm 0.59$ & 0.805 \\
\hline $\mathrm{GFR}, \mathrm{mL} / \mathrm{min} / 1.73 \mathrm{~m}^{2}$ & $26.66 \pm 7.36$ & $29.52 \pm 11.67$ & 0.512 \\
\hline $\mathrm{NGAL}, \mathrm{ng} / \mathrm{ml}$ & $11455.00 \pm 2785.20$ & $13937.76 \pm 5068.65$ & 0.188 \\
\hline Albumin, mg/dL & $27.55 \pm 4.74$ & $23.52 \pm 10.58$ & 0.292 \\
\hline SGOT, $\mu / l$ & $55.33 \pm 45.59$ & $140.41 \pm 88.82$ & $0.013^{*}$ \\
\hline SGPT, $\mu / l$ & $51.44 \pm 41.34$ & $75.00 \pm 53.05$ & 0.259 \\
\hline Bilirubin Total, mg/dL & $2.00 \pm 1.23$ & $8.21 \pm 8.23$ & 0.035 \\
\hline Bilirubin Direk, mEq/L & $1.77 \pm 2.37$ & $5.27 \pm 6.40$ & 0.130 \\
\hline INR & $1.43 \pm 0.44$ & $1.60 \pm 0.44$ & 0.352 \\
\hline CTP & $8.55 \pm 0.52$ & $10.94 \pm 0.82$ & $0.001^{* *}$ \\
\hline
\end{tabular}

In table 3, there was a significant correlation between CTP and leukocytes, thrombosit, $\mathrm{Cl}$, creatinine, GFR, Albumin, total bilirubin and direct bilirubin. 
Table 3 Correlation between CPT with inflammatory parameters of liver cirrhosis with hepatorenal syndrome patients

\begin{tabular}{|c|c|c|}
\hline Parameter & $\mathbf{r}$ & $p$ \\
\hline Age, yr & 0.340 & 0.089 \\
\hline $\mathrm{BW}, \mathrm{Kg}$ & 0.019 & 0.927 \\
\hline $\mathrm{Hb}, \mathrm{gr} / \mathrm{dL}$ & -0.185 & 0.366 \\
\hline Leukosit, sell/mm³ & $-0.436^{*}$ & $0.026^{*}$ \\
\hline Trombosit, sell $/ \mathrm{mm}^{3}$ & $-0.425^{*}$ & $0.030^{*}$ \\
\hline $\mathrm{Na}, \mathrm{mEq} / \mathrm{L}$ & 0.334 & 0.095 \\
\hline $\mathrm{K}, \mathrm{mEq} / \mathrm{L}$ & 0.047 & 0.820 \\
\hline $\mathrm{Cl}, \mathrm{mEq} / \mathrm{L}$ & $0.677^{* *}$ & $0.001^{\star \star}$ \\
\hline Ureum, mg/dL & -0.287 & 0.155 \\
\hline Creatinin, mg/dL & $0.459^{*}$ & $0.018^{*}$ \\
\hline $\mathrm{GFR}, \mathrm{mL} / \mathrm{min} / 1.73 \mathrm{~m}^{2}$ & $-.561^{* *}$ & $0.003^{*}$ \\
\hline NGAL, ng/ml. & 0.201 & 0.324 \\
\hline Albumin, mg/dL & $0.571^{* \star}$ & $0.002^{*}$ \\
\hline SGOT, $\mu / l$ & 0.382 & 0.054 \\
\hline SGPT, $\mu / l$ & 0.047 & 0.820 \\
\hline Bilirubin Total, mg/dL & $0.677^{\star *}$ & $0.001^{* *}$ \\
\hline Bilirubin Direk, mEq/L & $0.571^{\star *}$ & $0.002^{*}$ \\
\hline INR & 0.382 & 0.054 \\
\hline
\end{tabular}

\section{Discussion}

The child-Pugh score was firstly proposed by Child and Turcotte to predict the operative risk in patients undergoing portosystemic shunt surgery for variceal bleeding. The primary version of the Child-Pugh score included ascites, hepatic encephalopathy (HE), nutritional status, total bilirubin, and albumin. Pugh et al [10] modified the Child-Pugh classification by adding prothrombin time or an international normalized ratio (INR) and removing nutritional status. The Child-Pugh score has been widely used to assess the severity of liver dysfunction in clinical work. Model for end-stage liver disease (MELD) score was initially created to predict the survival of patients undergoing transjugular intrahepatic portosystemic shunts (TIPS). [11] The primary version of the MELD score included the etiology of liver cirrhosis, but this variable was unnecessary. [12] The present version of the MELD score incorporated only 3 objective variables, including total bilirubin, creatinine, and INR. Currently, it has been used to rank the priority of liver transplantation (LT) candidates. Child-Pugh and MELD scores have been widely used to predict the outcomes of cirrhotic patients. However, they have some drawbacks. First, 2 variables (i.e. ascites and HE) included in the Child-Pugh score are subjective and may be variable according to the physicians' judgment and the use of diuretics and lactulose. Second, INR, which 
is one component of both Child-Pugh and MELD scores, does not sufficiently reflect coagulopathy and consequently liver function in liver cirrhosis. [13] Third, there is an interlaboratory variation in INR value. [14]

The routine use of these classifications has revealed some problems. First, both the degree of ascites and encephalopathy are subjective assessments evaluated by physical examination alone. The widespread use of ultrasonography has led to more sensitive detection of ascites, but it is unclear how ascites diagnosed by ultrasonography alone is being categorized by various authors. Hepatic encephalopathy (HE) is often assessed by psychometric testing or slowing of frequency on electroencephalography (EEG). It is not clear how these abnormalities are fitted into CTP classification. Secondly, both ascites and HE can be influenced by therapy such as diuretics, albumin infusion, and lactulose and it is not clear if ascites and HE are scored at their best, or worst, or independent of a specific therapy. As regards the continuous variables in the CTP classification, they are categorized with arbitrary cut-off points. Thus, patients with a bilirubin of 55 um have a better prognosis than those with a bilirubin of $250 \mathrm{um}$; in the CTP classification, both these patients have the same score of severity for bilirubin concentration ('the ceiling effect'). Changes in bilirubin concentration with specific therapy such as ursodeoxycholic acid (for which improvements are in doubt) are difficult to interpret using CTP classification [15]. A similar problem exists for serum albumin so that the CTP classification does not differentiate between patients with albumin of $17 \mathrm{~g} / \mathrm{L}$ vs. $25 \mathrm{~g} / \mathrm{L}$ ('the floor effect').

The International Normalized Ratio (INR) now overcomes this using a standardized thromboplastin reagent. The conversion from INR to PT and vice versa using a nomogram is not used routinely and INR has not been incorporated into the CTP score. Although it would seem sensible to use INR, it should be remembered that INR was designed to standardize the anticoagulation effect of warfarin and not to evaluate the severity of the liver disease. As a result, INR may not be valid to assess liver impairment, [16] despite its use in a model for end-stage liver disease (MELD) scoring.

Partly due to the grading system, the CTP classification does not distinguish the 'mild' grade C from the severe grade $\mathrm{C}$ patient with sufficient clinical discrimination. Moreover, it does not include a measure of renal function, which is a well-established prognostic marker interpret using CTP classification. Exists for serum albumin so that the CTP classification does not differentiate between patients with albumin of $17 \mathrm{~g} / \mathrm{L}$ vs. $25 \mathrm{~g} / \mathrm{L}$ ('the floor effect'). The increased use of intravenous albumin if given close to an assessment may further complicate the interpretation. This model was found to be superior to both CTP classification and score in predicting survival, especially in patients with CTP class B with impaired renal function. A similar problem published an article on cirrhosis, as well as in acute liver disease. [17] 
In this study, the difference in important inflammatory parameters between the levels of Child-

Pug B and Child-Pug C was not significant, nor the correlation of CPT parameters with important inflammatory parameters as a prognostic factor.

\section{Conclusion}

There is no clear difference in inflammatory parameters of Child-Pug B and Child-Pug C scores in liver cirrhosis with hepatorenal syndrome.

\section{REFERENCES}

[1] Kim SU, Han KH, Nam CM, et al. " Natural history of hepatitis B virus-related cirrhotic patients hospitalized to control ascites.," J Gastroenterol Hepatol, vol. 23: p. 1722.e7. , 2008.

[2] Wray CJ, Harvin JA, Silberfein EJ, et al. " prognostic model of extremely poor survival among high-risk hepatocellular carcinoma patients.," Cancer , vol. 118:, p. 6118e25., 2012

[3] Zhu L, Li J, Dong X, et al. "Hospital costs and length of hospital stay for hepatectomy in patients with hepatocellular carcinoma: results of a prospective case series.," Hepatogastroenterology, vol. 58:, p. 2052e 7, 2011.

[4] Rajendra A, Wong JB. "Economics of chronic hepatitis B and hepatitis C.," J Hepatol, vol. 47:, p. 608e17, 2007.

[5] Lange Christian M. "Systemic inflammation in hepatorenal syndrome; A target for novel treatment strategies?," Liver Int , vol. 39:, p. 1199-201. Available from: https://doi.org/10.1111/liv.14057, 2019.

[6] Ripoll C, Groszmann R, Garcia-Tsao G, Grace N, Burroughs A, Planas R, et al., "Hepatic venous pressure gradient predicts clinical decompensation in patients with compensated cirrhosis.," Gastroenterology, vol. 133, no. (2):, p. 481-8. 2007.

[7] Ginès P, Solà E, Angeli P, Wong F, Nadim MK, Kamath PS. "Hepatorenal syndrome.," Nat Rev Dis Primers, vol. 4 (no. 1), pp. 33. 2018. Available from: https://www.nature.com/ articles/s41572-018-0022-7.

[8] E. Cholongitas; G. V. Papatheodoridis; M. Vangeli; N. Terreni; D. Patch; A. K. Burroughs , "Systematic review: the model for end-stage liver disease - should it replace Child-Pugh's classification for assessing prognosis in cirrhosis," vol. 22, pp. (11-12), 1, 2005.

[9] Salerno F, Gerbes A, Gines P, et al. , "Diagnosis, prevention and treatment of the hepatorenal syndrome in cirrhosis a consensus workshop of the International Ascites Club.," Gut, vol. 56:., p. 1310-1318, 2007.

[10] Pugh RN, Murray-Lyon IM, Dawson JL, et al. "Transection of the oesophagus for bleeding oesophageal varices." Br J Surg, vol. 60: p. 646-649, 1973.

[11] M, Kamath PS, Gordon FD, et al. "A model to predict poor survival in patients undergoing transjugular intrahepatic portosystemic shunts.," Hepatology (Baltimore, MD) , vol. 31: p. 864-871, 2000.

[12] Kamath PS, Kim WR, "Advanced Liver Disease Study G. The model for end-stage liver disease (MELD)," Hepatology (Baltimore, MD). vol. 45, p. 797-805, 2007.

[13] Bedreli S, Sowa JP, Gerken G, et al. "Management of acute-onchronic liver failure: rotational thromboelastometry may reduce substitution of coagulation factors in liver cirrhosis," Gut, vol. 65: p. 357-358, 2016. 
[14] . 8. Trotter JF, Olson J, Lefkowitz J, et al. "Ch anges in international normalized ratio (INR) and model for endstage liver disease (MELD) based on selection of clinical laboratory.," Am J Transplant. , vol. 7: p. 1624-1628. 2007.

[15] Chan CW, Gunsar F, Feudjo M, etal. "Long-term ursodeoxycholic acid therapy for primary biliary cirrhosis: a follow-up to 12 years.," Aliment Pharmacol Ther, vol. 21, p. 217-26, 2005.

[16] Robert A, "Chazouilleres O. Prothrombin time in liver failure: time, ratio, activity percentage, or International Normalized Ratio?," Hepatology, vol. 24: p. 1392-4, 1996;

[17] Fernandez-Esparrach G, Sanchez-Fueyo A, Gines P, et al. , "A prognostic model for predicting survival in cirrhosis with ascites," J Hepatol, vol. 34: p. 46-52., 2001. 